\title{
ASSESSING SURFACE WATER QUALITY IN FRESHWATER RESERVOIRS IN AN GIANG PROVINCE, VIET NAM
}

\author{
Nguyen Thanh Giao ${ }^{1}$
}

\begin{abstract}
Water quality is critical for a healthy ecosystem, this study was conducted to evaluate the surface water quality in lakes in An Giang Province from 2017 to 2019. Water quality was assessed using variables of temperature, $\mathrm{pH}$, dissolved oxygen (DO), total suspended solids (TSS), chemical oxygen demand $(C O D)$, biological oxygen demand $(B O D)$, nitrate $\left(\mathrm{NO}_{3^{-}}-\mathrm{N}\right)$, phosphate $\left(\mathrm{PO}_{4}^{3-}-\mathrm{P}\right)$, ammonia $\left(\mathrm{NH}_{4}^{+}-\mathrm{N}\right)$, and coliforms at nine locations belonging to seven reservoirs including $O$ Tuk Sa, Thuy Liem, Soai So, Soai Chek, O Thum, $O$ Ta Soc, and Bung Binh Thien. Water quality criteria were assessed according to the National Technical Regulation on Surface Water Quality (QCVN 08-MT: 2015/BTNMT). Cluster analysis (CA) and principal component analysis (PCA) were applied to group water quality to identify the main parameters affecting water quality in the reservoirs. The findings indicated that the water quality in the reservoirs were polluted by TSS, organic matters (DO was low, while COD and BOD were high), and microorganisms (coliforms). The PCA analysis showed that the water variables including temperature, $p H, D O, T S S$, $\mathrm{COD}, \mathrm{BOD}, \mathrm{NO}_{3^{-}}-\mathrm{N}, \mathrm{PO}_{4}^{3-}-\mathrm{P}, \mathrm{NO}_{3^{-}}-\mathrm{N}$, and coliforms significantly influenced the surface of the water in the reservoirs. It is necessary to investigate pollution sources to propose appropriate solutions to treat and maintain the water quality in the reservoirs of An Giang Province.
\end{abstract}

Keywords: An Giang Province, coliforms, lakes, organic pollution, principal component analysis, water quality.

\footnotetext{
${ }^{1}$ Can Tho University

Email: ntgiao@ctu.edu.vn

Received date: $19^{\text {th }}$ June 2020; Revised date: $26^{\text {th }}$ November 2020; Accepted date: $20^{\text {th }}$ December 2020
}

\section{INTRODUCTION}

A system of lakes is one of the main features of Vietnam's natural topography, the Vietnamese Mekong Delta (VMD), which plays an important role in many aspects of life. Reservoirs help strengthen the storage and regulation of freshwater, provide water for domestic use and agricultural production in the dry season, and act as flood control in the rainy season. Furthermore, it also helps to irrigate fields and raise aquaculture. In particular, these bodies of water also play a role in regulating the climate in the region, creating ecological landscapes, as resorts and ecotourism, protecting biodiversity and the environment.

The study areas are the lakes in three districts of An Phu, Tinh Bien and Tri Ton, all in An Giang Province. The lakes in these districts are planned for tourism and to provide water for human activities. According to Tinh Bien district's assessment, the surface water is being polluted, it can only be used after proper treatment for production and daily life in the dry season. Most of the area around the lakes are inhabited by several households, where pollution sources are mainly from domestic activities, feces of cattle and poultry from livestock, wastes from unprocessed production and business establishments discharged directly into lakes contaminating these important water sources. In the context of climate change causing shortage of freshwater for life and production, maintaining water quality in the lakes is an extremely important task. This study assessed water quality in the lakes in An Giang Province to provide useful information on dynamics of lake water quality for better management of these water resources.

\section{BACKGROUND}

There have been certain studies on water quality in lakes to timely assess water quality and 
propose management solutions to help protect the environment and contribute to socio-economic development. Research on factors affecting water quality of Da Den lake has shown that water quality of $\mathrm{Da}$ Den lake is being negatively affected by socio-economic activities such as agricultural activities, animal husbandry, industry, production, and urban development [1]. This study reported that water variables of chemical oxygen demand (COD), biological oxygen demand (BOD), total suspended solids (TSS), ammonium $\left(\mathrm{NO}_{3^{-}}-N\right)$, nitrate $\left(\mathrm{NO}_{3^{-}}-N\right)$, and coliforms exceeded the permissible standards in 2010 and 2011. Van et al. [2] studied water quality in the West Lake and concluded that the lake water quality had signs of pollution of organic matter, nutrients and coliforms.

To effectively obtain good information in the monitoring or environmental data, multivariate statistical methods can be applied [3]. Using multivariate statistical techniques would allow one to reduce data dimensions and interpret the analyzed environmental data with insignificant loss of information in the initial dataset [4]. Multivariate statistical techniques were successfully applied for explaining spatial and temporal water quality data in rivers $[3,4]$, identifying sources of water pollution $[3,5]$, designing sampling networks [6], and extracting the most crucial water quality parameters for evaluating water quality variability [7]. In Viet Nam, Nhan [8] used data on population, industrial production, agriculture, and services to find the three main socio-economic regions of Tra Vinh using CA and PCA, and $\mathrm{Au}$ et al. [9] used multivariate analysis of CA and PCA to assess groundwater quality - and to evaluate the surface water monitoring system on Hau river [10].

\section{MATERIALS AND METHODS}

\section{A. Study areas}

The study areas in An Giang Province included three districts of An Phu, Tinh Bien and Tri Ton. The lakes included O Tuk Sa lake, Thuy Liem lake, Soai So lake, Soai Chêk lake, O Thum lake, O Ta Soc lake, and Bung Binh Thien lake. These research sites are used for tourism, wetland ecology conservation (Bung Binh Thien), water quality control, and domestic uses. The location map of the sampling points was shown in Figure 1.

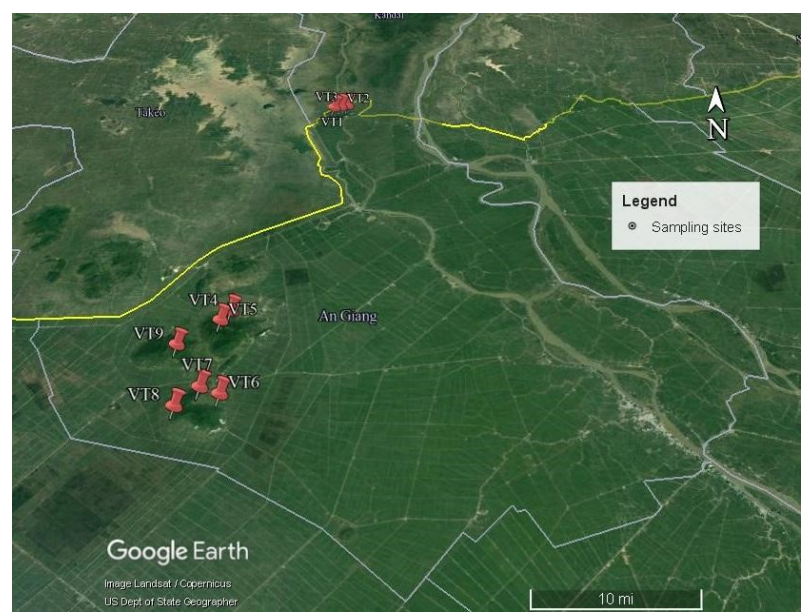

Fig. 1: Locations of lake water sampling

(Source: Google earth, 2020)

\section{B. Data collection and analysis}

The data of surface water quality was collected at nine locations over a period of three years (2017 to 2019). At Bung Binh Thien lake, three samples were collected and symbolized as VT1, VT2, VT3 respectively; O Tuck Sa lake (VT4); Thuy Liem lake (VT5); Soai So (VT6); Soai Che k lake (VT7); O Thum lake (VT8) and Ta Soc lake (VT9). The parameters included $\mathrm{pH}$, dissolved oxygen (DO, $\mathrm{mg} / \mathrm{L})$, and temperature which were measured at the fields, whereas total suspended solids (TSS, mg/L), biological oxygen demand $(\mathrm{BOD}, \mathrm{mg} / \mathrm{L})$, chemical oxygen demand (COD, $\mathrm{mg} / \mathrm{L})$, nitrate $\left(\mathrm{NO}_{3^{-}}-N, \mathrm{mg} / \mathrm{L}\right)$, ammonia $\left(\mathrm{NO}_{3^{-}}-N, \mathrm{mg} / \mathrm{L}\right)$, and orthophosphate $\left(\mathrm{PO}_{4}^{3-}-P, \mathrm{mg} / \mathrm{L}\right)$ were measured in the laboratory using standard methods. Water quality indicators were collected, stored, and analyzed as indicated in Table 2.

Data for yearly differences in water quality at the sampling locations was analyzed by a one-way analysis of variance (one-way ANOVA) method at a significant level of $5 \%$ by Duncan test using IBM SPSS statistics for Windows software Version 20.0 (IBM Corp. Armonk, NY, USA). After that, water quality analysis data 
Table 1: Characteristics of sampling locations

\begin{tabular}{|c|c|c|c|c|}
\hline Sign & $\mathbf{x}$ & $\mathbf{Y}$ & Lake & Description of sampling locations \\
\hline VT1 & $10^{0} 55^{\prime} 6,33^{\prime \prime} \mathrm{N}$ & $105^{0} 18^{\prime} 34,4^{\prime \prime} \mathrm{E}$ & Bung Binh Thien lake & Tourism, conservation of flooded ecosystems \\
\hline VT2 & $10^{0} 55^{\circ} 4,90^{\prime \prime} \mathrm{N}$ & $105^{0} 19^{\prime} 11,09^{\prime \prime} \mathrm{E}$ & Bung Binh Thien lake & Tourism, conservation of flooded ecosystems \\
\hline VT3 & $10^{0} 55^{\prime} 23,17^{\prime} \mathrm{N}$ & $105^{0} 19^{\prime} 57,98^{\prime \prime} \mathrm{E}$ & Bung Binh Thien lake & Tourism, conservation of flooded ecosystems \\
\hline VT4 & $10^{0} 29^{\prime} 27,64^{\prime \prime} \mathrm{N}$ & $105^{0} 14^{\prime} 51,21^{\prime} \mathrm{E}$ & O Tuk Sa lake & $\begin{array}{l}\text { Controlling the water quality of O Tuk Sa } \\
\text { lake, serving daily life }\end{array}$ \\
\hline VT5 & $10^{0} 30^{\prime} 11,94^{\prime \prime} \mathrm{N}$ & $105^{0} 1350,03^{\prime \prime} \mathrm{E}$ & Thuy Lien lake & $\begin{array}{l}\text { Controlling the water quality of Thuy Liem } \\
\text { lake, serving daily life }\end{array}$ \\
\hline VT6 & $10^{0} 23^{\prime} 33,47^{\prime \prime} \mathrm{N}$ & $105^{0} 15^{\prime} 4,90^{\prime \prime} \mathrm{E}$ & Soai So lake & $\begin{array}{c}\text { Controlling the water quality of Soai So lake, } \\
\text { serving daily life }\end{array}$ \\
\hline VT7 & $10^{0} 24^{\prime} 18,19^{\prime \prime} \mathrm{N}$ & $105^{0} 13^{\prime} 36,92^{\prime \prime} \mathrm{E}$ & Soai Chek lake & $\begin{array}{c}\text { Controlling the water quality of Soai Chek } \\
\text { lake, serving daily life }\end{array}$ \\
\hline VT8 & $10^{0} 22^{\prime} 37,57^{\prime \prime} \mathrm{N}$ & $105^{0} 12^{\prime} 8,94^{\prime \prime} \mathrm{E}$ & O Thum lake & $\begin{array}{c}\text { Controlling the water quality of } \mathrm{O} \text { Thum lake, } \\
\text { serving daily life }\end{array}$ \\
\hline VT9 & $10^{0} 27^{\prime} 34,26^{\prime \prime} \mathrm{N}$ & $105^{0} 11^{\prime} 24,6^{\prime \prime} \mathrm{E}$ & O Ta Soc lake & $\begin{array}{c}\text { Controlling the water quality of O Ta Soc } \\
\text { lake, serving daily life }\end{array}$ \\
\hline
\end{tabular}

Table 2: Water quality variables and analysis

\begin{tabular}{|c|c|c|c|}
\hline STT & Variables & Unit & $\begin{array}{l}\text { Analytica } \\
\text { l method }\end{array}$ \\
\hline 1 & Temperature & ${ }^{0} \mathrm{C}$ & $\begin{array}{l}\text { SMEWW } \\
2550 \mathrm{~B}: 20 \\
12 \\
\text { TCVN }\end{array}$ \\
\hline 2 & $\mathrm{pH}$ & - & $\begin{array}{l}6492: 201 \\
1\end{array}$ \\
\hline 3 & $\begin{array}{l}\text { Total suspended } \\
\text { solids (TSS) }\end{array}$ & $\mathrm{mg} / \mathrm{L}$ & $\begin{array}{l}\text { SMEWW } \\
2540 \mathrm{D}: 20 \\
12\end{array}$ \\
\hline 4 & $\begin{array}{l}\text { Dissolved } \\
\text { oxygen (DO) }\end{array}$ & $\mathrm{mg} / \mathrm{L}$ & $\begin{array}{l}\text { TCVN } \\
7325: 200 \\
4\end{array}$ \\
\hline 5 & $\begin{array}{l}\text { Biological } \\
\text { oxygen demand } \\
\text { (BOD) }\end{array}$ & $\mathrm{mg} / \mathrm{L}$ & $\begin{array}{l}\text { SMEWW } \\
5210 \mathrm{~B}: 20 \\
12\end{array}$ \\
\hline 6 & $\begin{array}{l}\text { Chemical } \\
\text { oxygen demand } \\
\text { (COD) }\end{array}$ & $\mathrm{mg} / \mathrm{L}$ & $\begin{array}{l}\text { SMEWW } \\
5220 \mathrm{C}: 20 \\
12\end{array}$ \\
\hline 7 & Nitrate $\left(\mathrm{NO}_{3}{ }^{-}-\mathrm{N}\right)$ & $\mathrm{mg} / \mathrm{L}$ & $\begin{array}{l}\text { SMEWW } \\
4500- \\
\mathrm{NO}_{3}^{-2}- \\
\mathrm{E}: 2012\end{array}$ \\
\hline 8 & $\begin{array}{l}\text { Amoni }\left(\mathrm{NH}_{4}{ }^{+}-\right. \\
\mathrm{N})\end{array}$ & $\mathrm{mg} / \mathrm{L}$ & $\begin{array}{l}\text { SMEWW } \\
4500- \\
\mathrm{NH}_{3} \cdot \mathrm{B} \& \mathrm{~F} \\
: 2012\end{array}$ \\
\hline 9 & $\begin{array}{l}\text { orthophosphate } \\
\left(\mathrm{PO}_{4}^{3-}-\mathrm{P}\right)\end{array}$ & $\mathrm{mg} / \mathrm{L}$ & $\begin{array}{l}\text { SMEWW } \\
4500-\mathrm{P}- \\
\mathrm{E}: 2012\end{array}$ \\
\hline 10 & Coliforms & $\mathrm{MPN} / 100 \mathrm{~mL}$ & $\begin{array}{l}\text { TCVN } \\
6187- \\
2: 1996 \\
\end{array}$ \\
\hline
\end{tabular}

was used to calculate WQI water quality index and Cluster analysis and Principle component analysis.

The water quality index was calculated by the formula (1): In which:

WQII: The results of the calculation for parameter group I $(\mathrm{pH})$

WQIII: The results of the calculation for parameter group II (DO, BOD, $\mathrm{COD}, \mathrm{NO}_{3^{-}}-N$, $\left.\mathrm{NO}_{3^{-}}-N, \mathrm{PO}_{4}^{3-}-P\right)$

WQIIII: The results of the calculation for parameter group III (Coliforms)

The Viet Nam Environment Administration (2019) uses the water quality index (WQI) to classify water quality. The water quality is assessed according to 6 levels based on the WQI index from 0 to 100 . Level 1 , very good water quality with the WQI index ranging from 91-100, can be used as drinking water. Level 2, good water quality, WQI values from 76 to 90 are used for domestic water but appropriate treatment is needed. Level 3 is the average water quality used for irrigation and similar purposes, with a WQI from 51 to 75 . WQI values between 26 and 50 are classified as poor water quality (Level 4) suitable only for transport purposes. Level 5 with values from 10 to 25 indicates the quality of 
heavily polluted water, which requires treatment in the future. Finally, water with a WQI index $<10$ indicates that the water environment is heavily polluted (Level 6), contaminated water requires immediate treatment.

Mean values of bio-physicochemical parameters at all locations were input sources for Cluster analysis (CA) and Principal Component Analysis (PCA). Cluster Analysis (CA) was used to group water quality by locations in the way that the same water quality locations are grouped in the same clusters and vice versa. The CA was implemented according to Ward's method and represented by a dendrogram [11]. Principal Component Analysis (PCA) is the axis rotation method using Varimax [4]. PCA was used to reduce the starting parameters that do not cause the variation of the whole dataset. The origin variables were placed in forms of principal components and their relationships were illustrated by the weighing factors ranging from -1 to 1 [12]. The absolute value of the weighted correlation coefficient greater than 0.75 means that the correlation between the main component and the water quality parameter is close, $0.75-0.5$ is the medium correlation, and $0.5-0.3$ is weakly correlated [12]. CA and PCA were performed using copyrighted software Primer V5.2.9 (PRIMER-E Ltd, Plymouth, UK).

\section{RESULTS AND DISCUSSION}

\section{A. Water quality in the lakes}

The quality of surface water in the lakes in An Giang Province during a period of 3 years from 2017 to 2019 was presented in Table 3. The $\mathrm{pH}$ in the lakes ranged from $7.10 \pm 0.04$ to $7.51 \pm 0.37$, within the permitted limits of QCVN 08-MT: 2015/BTNMT, Column A1 [13]. The mean temperature in the lakes ranged from $28.03 \pm 0.90$ to $29.93 \pm 0.48^{\circ} \mathrm{C}$. This result is consistent with the temperature range for the development of aquatic species is 25 to $32^{\circ} \mathrm{C}$ [14]. A previous study in the canals of An Giang also showed that the temperature fluctuated between 29 to $30^{\circ} \mathrm{C}$ between 2009 and 2016 [15]. The dissolved oxygen (DO) concentration through the sampling places was lower than the permitted standard, having the highest value of $5.85 \pm 0.76 \mathrm{mg} / \mathrm{L}$ recorded at VT5 (Thuy Liem lake) and lowest at VT1 with a value of $4.62 \pm 0.55 \mathrm{mg} / \mathrm{L}$. The DO in the surface water environment in An Giang Province ranged from 4.0 to $5.2 \mathrm{mg} / \mathrm{L}$ [15] which was in the same range with the current study.

The mean values of water quality indicators including TSS, COD, BOD, and coliforms in all research locations exceeded the permissible thresholds according to QCVN 08-MT: 2015/BTNMT [13], Column A1 (Table 3). TSS, COD, BOD, and coliform at VT7 (Soai Chek lake) were highest and exceeded the permitted limits of QCVN 08-MT: 2015/BTNMT, Column A1[13]. Specifically, TSS values at VT7 ranged from $34.89 \pm 9.34$ to $177.22 \pm 201.46 \mathrm{mg} / \mathrm{L}$, 8 times higher than the standard; COD has the lowest value at VT6 $(18.00 \pm 4.38 \mathrm{mg} / \mathrm{L})$ and the highest at VT7 $(57.57 \pm 37.73 \mathrm{mg} / \mathrm{L})$; similarly, BOD of VT7 exceeded 9 times ranging from $11.67 \pm 2.80$ to $37.33 \pm 24.18 \mathrm{mg} / \mathrm{L}$; the lowest coliform was $3,633 \pm 728 \mathrm{MPN} / 100 \mathrm{~mL}$, the highest was $20,507 \pm 45,235 \mathrm{MPN} / 100 \mathrm{~mL}, 8$ times higher than the permitted levels. The results of this study were in line with the former studies that reported that the water quality in the Mekong Delta of Viet Nam has long been polluted by TSS, COD, BOD, and coliforms [10, 15-17]. Total suspended solids resulted in cost concern for water supply, transporting contaminants including microorganisms, heavy metals, and pesticides [16]. BOD could lead to formation of disinfection byproducts (DBPs) where chlorine mixed with treated water containing organic carbon could pose high risk to human health [18]. Former study found that BOD in the surface waters in An Giang Province ranged from $4.7 \pm 2.3$ to $12.3 \pm 9.2$ $\mathrm{mg} / \mathrm{L}$ [15]; BOD and COD in canals in Soc Trang Province was $2.2-22.4$ and $6.0-44.9 \mathrm{mg} / \mathrm{L}$, respectively [17]; and COD in Hau river was in the range of $10.4 \pm 1.2-16.5 \pm 4.1 \mathrm{mg} / \mathrm{L}$ [10]. Both BOD and COD were used as indicators of organic waste concentration in water $[19,20]$. Previous studies reported that the coliforms in surface water in An Giang, Soc Trang, and Hau river were 2260-155000 MPN/100 mL, 2300$89000 \mathrm{MPN} / 100 \mathrm{~mL}$, and 1346-86338 MPN/100 $\mathrm{mL}$, respectively $[10,15,17]$. The occurrence of coliforms indicates waters have been receiving 
Table 3: Summary of water quality in the lakes

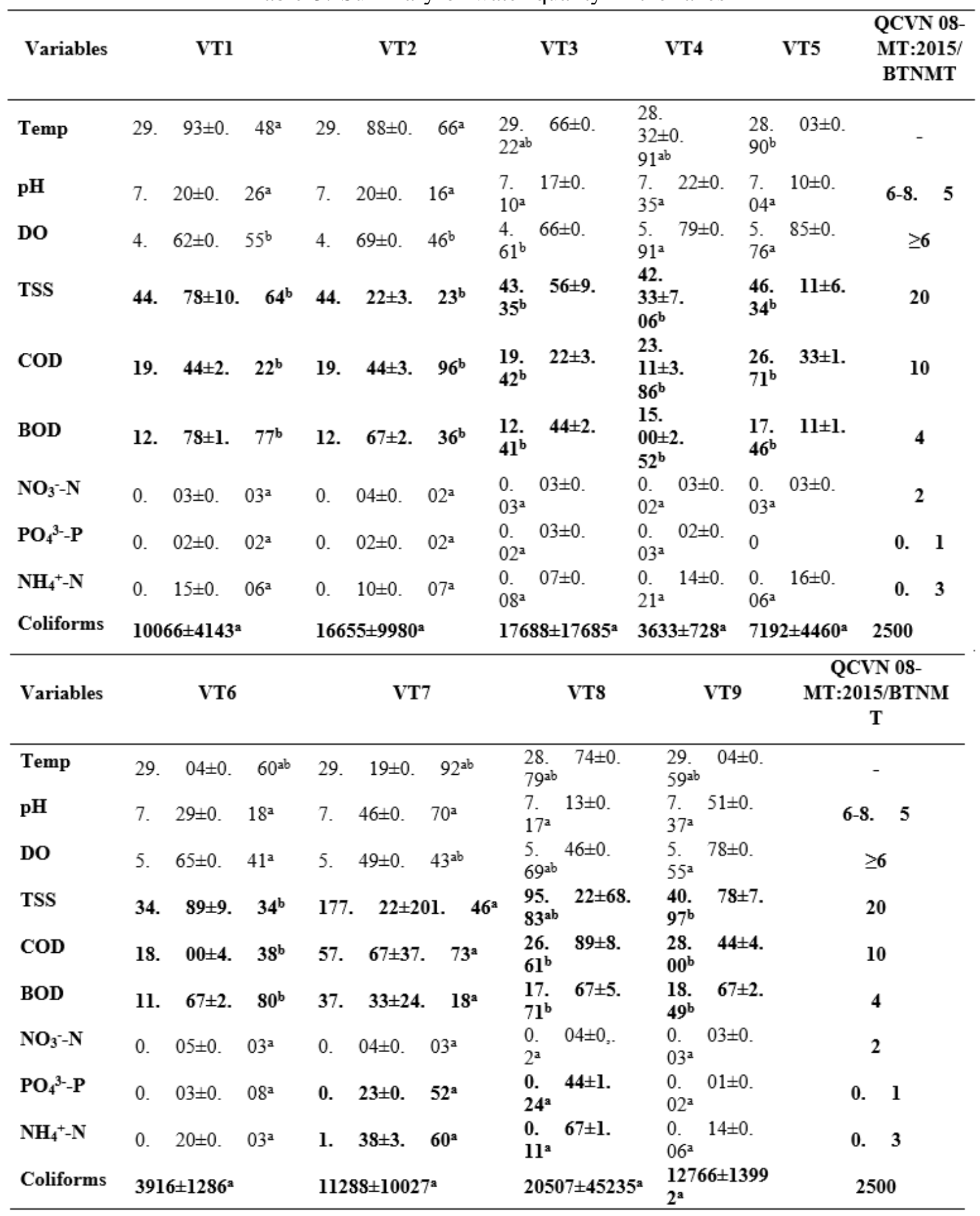

(Note: The values selected in the surface water standard QCVN 08-MT: 2015/BTNMT [13] in column Al is used for supply of water for living and conservation of aquatic plants and animals; mean $\pm S E(n=9), a, b$ : Different characters in the same row are statistically different at $5 \%$.) 
fecal materials from humans and animals [21]. The study areas were seriously polluted by organic matters and microorganisms; thus, it is not safe for domestic use.

The analysis results also showed that $\mathrm{NO}_{3^{-}}-$ $N$ values ranged from $0.07 \pm 0.08$ to $1.38 \pm 3.60$ $\mathrm{mg} / \mathrm{L}$. The highest concentrations of $\mathrm{NO}_{3^{-}}-\mathrm{N}$ were found at VT7 and VT8, exceeding the permitted level QCVN 08-MT: 2015/BTNMT, Column A1 [13]. A former study reported that $\mathrm{NO}_{3^{-}}-N$ in Hau Giang' waters was in the range of $0.27 \pm 0.16 \mathrm{mg} / \mathrm{L}$ [10]. Where the high levels of $\mathrm{NO}_{3^{-}}-N$ could cause toxicity for aquatic plants and its sources could be from degradation of organic matter, and fertilizers from agricultural activities. $\mathrm{NO}_{3^{-}}-N$ was low ranging from $0.03 \pm 0.02$ to $0.04 \pm 0.02 \mathrm{mg} / \mathrm{L}$. Previous studies have shown that $\mathrm{NO}_{3^{-}}-\mathrm{N}$ concentration in Hau river $0.002-0.395 \mathrm{mg} / \mathrm{L}$ [22], in canals in An Giang Province $0.31 \pm 0.3-0.58 \pm 0.64 \mathrm{mg} / \mathrm{L}$ [15], in surface water in Soc Trang Province 0.05$0.14 \mathrm{mg} / \mathrm{L}$ [17]. $\mathrm{NO}_{3^{-}}-N$ is likely to fluctuate over time, but $\mathrm{NO}_{3^{-}}-N$ rarely exceeded the QCVN 08-MT: 2015/BTNMT, column A1 (2 $\mathrm{mg} / \mathrm{L})$ [13]. $\mathrm{PO}_{4}^{3-}-P$ values ranged from 0 (VT5) to $0.44 \pm 0.24 \mathrm{mg} / \mathrm{L}$ (VT8). High concentrations of $\mathrm{PO}_{4}^{3-}-\mathrm{P}$ were found at VT7 and VT8, while the remaining locations had $\mathrm{PO}_{4}^{3-}-P$ found ranging from 0 to $0.03 \pm 0.02 \mathrm{mg} / \mathrm{L}$. Former studies presented that $\mathrm{PO}_{4}^{3-}-P$ in the waters of An Giang 0.02- $0.47 \mathrm{mg} / \mathrm{L}$ [15], in Hau river 0.04-0.11 mg/L [10], in Soc Trang 0.05-0.9 $\mathrm{mg} / \mathrm{L}$ [17]. There was no significant difference $(\mathrm{p}>0.05)$ in the water quality in all study sites. $\mathrm{PO}_{4}^{3-}-P$ was not the problem for water quality in the lakes, except VT7 (Soai Chek lake) and VT8 (O Thum lake). The sources of orthophosphate in the water environment are agricultural runoff, livestock, domestic and industrial wastes [23].

The results of WQI calculation showed that water quality at the locations VT1, VT2, VT3 (Bung Binh Thien), VT7 (Soai Chêk lake), VT8 (O Thum lake), VT9 (Ta Soc lake) are at level 5 (heavy pollution), and need to be treated in the future (Figure 2). While VT4 (O Tuck Sa lake) and VT6 (Soai So) have water quality that can be used for domestic purposes, appropriate treatment is needed; VT5 (Thuy Liem lake) can only be used for irrigation and other similar purposes. The results indicated that the water quality in Bung Binh Thien (An Phu District) and the water bodies of lakes (Soai So, Soai Chêk, O Thum, O Ta Soc in Tri Ton District) were more polluted than the reservoirs in Tinh Bien District (O Tuk Sa and Thuy Liem lakes).

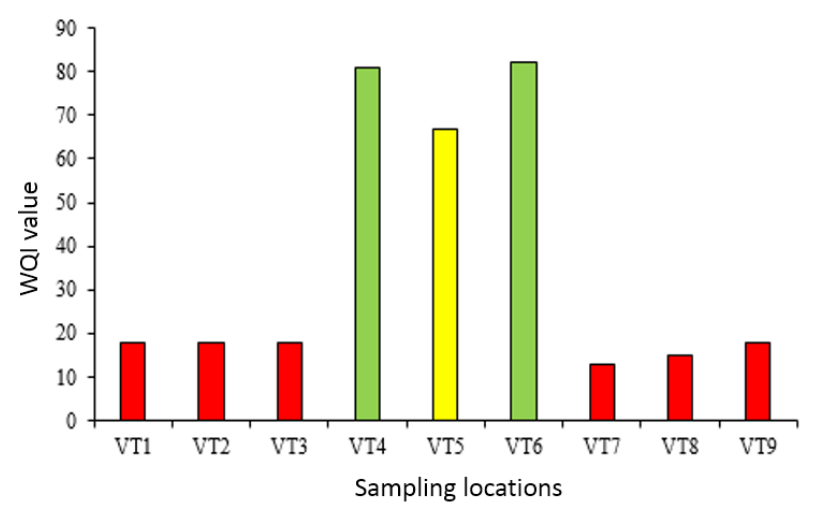

Fig. 2: Water quality index at the lakes

The CA result was presented in Figure 3. As can be seen that at distance 3 , water quality was divided into five clusters including, cluster 1 (VT7), cluster 2 (VT8), cluster 3 (VT1, VT2, and VT3), clusters 4 (VT9) and cluster 5 (VT4, VT5, VT6). The water quality division is relatively consistent with the previous WQI analysis. Water quality at Bung Binh Thien (VT1, VT2, and VT3) were distributed in the same group, clearly differentiated from the other lakes.

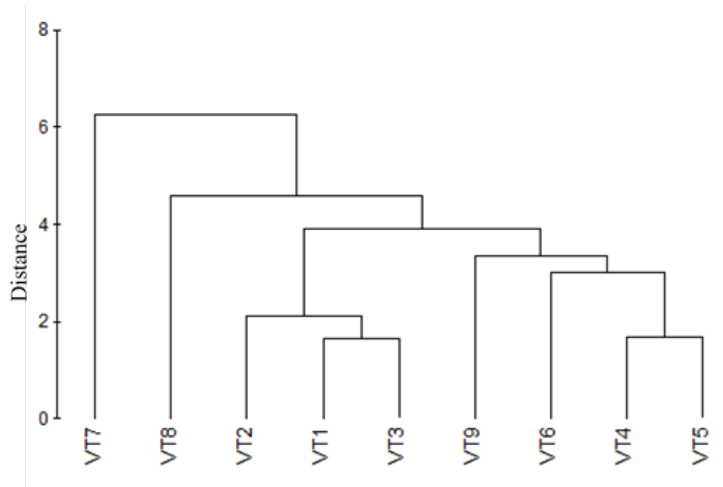

Fig. 3: Clustering water quality at the lakes 


\section{B. Key variables influencing water quality in the lakes}

The PCA result was presented in Table 4. PC1, PC2, PC3 and PC4 had the eigenvalues 4.61, 2.34, 1.41, and 1.02, respectively. Therefore, $\mathrm{PC} 1, \mathrm{PC} 2, \mathrm{PC} 3$ and PC4 are the main factors, or sources of pollutants, accounting for $93.8 \%$ of the total variation of surface water quality data in the lakes. The PCA results showed that the water quality indicators affecting water quality by PC1 were TSS, COD, BOD, $\mathrm{NO}_{3^{-}}-N$; PC2 was temperature, $\mathrm{DO}$ and coliforms; $\mathrm{PC} 3$ was $\mathrm{pH}$ and $\mathrm{PO}_{4}^{3-}-P ; \mathrm{NO}_{3-}-N$ in $\mathrm{PC} 4 . \mathrm{PC} 1$ explained $46.1 \%$ the variation of water quality in the lakes, mainly contributed by organic matters and total suspended solids. This is a typical form of pollution of lakes in the Mekong Delta, caused by people's daily habits, for instance discharging domestic waste into bodies of water. In addition, rainwater runoff and erosion also significantly contributed to increase the concentration of suspended solids and organic matter [10, 16, 24]. Wastes from agricultural activities, such as fertilizers and animal waste, also pollute water sources if not treated before being discharged into the environment. The use of fertilizers and pesticides as well as their release into the environment are one of the common causes of surface water pollution [16]. PCA results showed that the parameters of temperature, $\mathrm{pH}, \mathrm{DO}, \mathrm{TSS}$, $\mathrm{COD}, \mathrm{BOD}, \mathrm{NO}_{3^{-}}-N, \mathrm{PO}_{4}^{3-}-P, \mathrm{NO}_{3^{-}}-N$ and coliforms all have a significant impact on the quality of surface water at the lakes. This information has been recorded in some previous studies by Ty [24], Giao [10] and Giao [25] in the Mekong Delta and Bung Binh Thien lake. However, the number of analyzed parameters may have limited the principal component analysis, which could mean that when more water quality parameters were added, the better selection of key water parameters influencing the water quality.

\section{CONCLUSION}

The results of the study showed that water quality in the lakes in An Giang Province in the period of 2017 to 2019 was polluted by low DO, high TSS, COD, BOD, $\mathrm{PO}_{4}^{3--}-P, \mathrm{NO}_{3^{-}}-N$, and coliforms. The main sources of water pollution
Table 4. Key water parameters influencing water quality in the lakes

\begin{tabular}{lccccc}
\hline Parameter & PC1 & PC2 & PC3 & PC4 & PC5 \\
\hline Temp & - & $\mathbf{0 . 5 3 7}$ & -0.401 & 0.248 & 0.054 \\
$\mathrm{pH}$ & 0.246 & 0.114 & $\mathbf{- 0 . 5 2 0}$ & 0.341 & - \\
$\mathrm{DO}$ & 0.156 & $\mathbf{0 . 5 6 2}$ & 0.228 & 0.062 & - \\
$\mathrm{TSS}$ & $\mathbf{0 . 4 4 9}$ & -0.122 & 0.011 & -0.047 & 0.245 \\
$\mathrm{COD}$ & $\mathbf{0 . 4 4 9}$ & 0.051 & -0.177 & -0.079 & 0.122 \\
$\mathrm{BOD}$ & $\mathbf{0 . 4 4 9}$ & 0.049 & -0.175 & -0.081 & 0.111 \\
$\mathrm{NO}_{3}{ }^{-} \mathrm{N}$ & 0.057 & -0.171 & 0.398 & $\mathbf{0 . 8 1 8}$ & 0.024 \\
$\mathrm{PO}_{4}{ }^{3-}-\mathrm{P}$ & $\mathbf{0 . 3 0 1}$ & -0.229 & $\mathbf{0 . 5 2 3}$ & -0.084 & - \\
$\mathrm{NH}_{4}{ }^{+}-\mathrm{N}$ & $\mathbf{0 . 4 5 4}$ & -0.083 & 0.058 & 0.041 & 0.207 \\
Coliforms & 0.060 & $\mathbf{- 0 . 5 2 4}$ & 0.138 & -0.355 & - \\
\hline $\begin{array}{l}\text { Eigenvalue } \\
\text { Variation }\end{array}$ & 4.61 & 2.34 & 1.41 & 1.02 & 0.51 \\
$\begin{array}{l}\text { (\%) } \\
\text { Cum.Var } \\
\text { (\%) }\end{array}$ & 46.1 & 23.4 & 14.1 & 10.2 & 5.1 \\
\hline
\end{tabular}

could be potentially from rainwater runoff, livestock, poultry, farming, and community activities. The results of WQI assessment showed that water quality in the lakes in An Phu and Tri Ton Districts were more polluted than that in Tinh Bien. Water quality in these water bodies only met the water requirements for agricultural production, and does not meet the requirements for domestic water supply. The PCA analysis showed that the water quality variables of temperature, $\mathrm{pH}, \mathrm{DO}, \mathrm{TSS}, \mathrm{COD}, \mathrm{BOD}, \mathrm{NO}_{3^{-}}-N, \mathrm{PO}_{4}^{3-}-\mathrm{P}$, $\mathrm{NO}_{3^{-}}-N$, and coliforms need to be monitored to assess water quality in the lakes. Future studies should focus on investigating and eliminating sources of pollution to maintain and improve surface water quality of the lakes in An Giang Province.

\section{ACKNOWLEDGEMENTS}

The author would like to thank the Department of Natural Resources and Environment of An Giang Province for data provided. Any opinions, findings, and conclusions or recommendations expressed in this material are those of the author and does not necessarily reflect the views of the data provider. 


\section{REFERENCES}

[1] Thang LV, Quan LH. Researching factors affecting the quality of Da Den lake water and proposing general management solutions. In Proceeding of scientific and technological research and application for period of 2013 - 2015; 2014.

[2] Van HTL, Cau LN, Dung BQ, Anh NTK, Tien NV, Giang NT et al. Assess the current situation of water quality in West Lake. Journal of Change Science Climate. 2019; 8:58-61.

[3] Chounlamany V, Tachuling MA, Inoue T. Spatial and temporal variation of water quality of a segment of Marikina river using multivariate tsatistical analyses. Water Science and Technology. 2017; 76:1510-1522.

[4] Feher IC, Zaharie M, Oprean I. Spatical and seasonal variation of organic pollutants in surface water using multivariate statistical techniqus. Water Science and Technology. 2016; 74:1726-1735.

[5] Vega M, Pardo R, Barrado E, Deban L. Assessment of seasonal and polluting effects on the quality of river water by exploratory data analysis. Water Research. 1998; 32:3581-3592.

[6] Singh KP, Malik A, Sinha S. Water quality assessment and apportionment of pollution sources of Gomti river (India) using multivariate statistical techniques-a case study. Analytica Chimica Acta. 2005; 538:355-374.

[7] Zeinalzadeh K, Rezaei E. Determining spatial and temporal changes of surface water quality using principal component analysis. Journal of Hydrology: Regional Studies. 2017; 13:1-10.

[8] Nhan TT. Application of statistical analysis techniques in assessing surface water quality: the case in Tra Vinh. Journal of Science and Technology. 2013; 10:11-18.

[9] $\mathrm{Au} \mathrm{NH}$, Ngan PTK, Thuy HTT, Ngoc PNH. Application of multivariate statistical analysis in assessing groundwater quality in Tan Thanh district, Ba Ria - Vung Tau Province. Science and Technology Development. 2017; 1(M2):66-72. DOI: https://doi.org/https://doi.org/10.32508/stdjsee.v1iM2. 446

[10] Giao NT. Evaluating Current Water Quality Monitoring System on Hau river, Mekong Delta, Viet Nam Using Multivariate Statistical Techniques. Applied Environmental Research. 2020; 42(1):14-25.

[11] Salah EAM, Turki AM, Othman EMA. Assessment of water quality of Euphrates river using cluster analysis. Journal of Environmental Protection. 2012; 3:1629_ 1633.

[12] Liu CW, Lin KH, Kuo YM. Application of factor analysis in the assessment of groundwater quality in a Blackfoot disease area in Taiwan. Science of the Total Environment. 2003; 313:77-89.

[13] Ministry of Environment and Natural Resources (MONRE). QCVN 08-MT: 2015/BTNMT National technical regulation on surface water quality; 2015.
[14] Boyd CE. Water quality for pond aquaculture. Research and development series. Auburn University Auburn, Alabama: International center for aquaculture and aquatic environments Alabama aquaculture experiment station Auburn University. 1998.

[15] Ly NHT, Giao NT. Surface water quality in canals in An Giang Province, Viet Nam, from 2009 to 2016. Journal of Vietnamese Environment. 2018; 10(2):113-119.

[16] Mekong river Commission. Annual water quality data assessment report. MRC Technical Paper; 2015.

[17] Tuan DDA, Thu BA, Trung NH. Assessing quality of surface water for urban water supply source for Soc Trang City. Scientific Journal of Can Tho University. 2019; 55(4):61-70.

[18] Ratpukdi T, Sinora S, Kiattisaksiri P, Punyapalakul P, Siripattanakul-Ratpukdi S. Occurrence of trihalomethanes and haloacetonitriles in water distribution networks of Khon Kaen Municipality, Thailand. Water Supply. 2019; 19(6):1748-1757.

[19] Galal-Gorchev H, Ozolins G, and Bonnefoy X. Revision of the WHO guidelines for drinking water quality. Annalidell'IstitutoSuperiore di Sanita. 1993; 29:335-345.

[20] Kazi TG, Arain MB, Jamali MK, Jalbani N, Afridi HI, Sarfraz RA et al. Assessment of water quality of polluted lake using multivariate statistical techniques: A case study. Ecotoxicology and Environmental Safety. 2009; 72(20):301-309.

[21] UNICEF Handbook on Water Quality. United Nations Children's Fund (UNICEF), New York; 2008.

[22] Lien NTK, Huy LQ, Oanh DTH, Phu TQ, Ut VN. Water quality in mainstream and tributaries of Hau river. Can Tho University Journal of Science. 2016; 43:68-79.

[23] Barakat A, Baghdadi ME, Rais J, Aghezzaf B, and Slassi M. Assessment of spatial and seasonal water quality variation of Oum Er Rbia river (Morocco) using multivariate statistical techniques. International Soil and Water Conservation Research. 2016; 4(4):284-292.

[24] Ty DV, Huy NH, Da CT, Ut VN, Viet TV. Evaluation of water quality in Binh Thien lagoon, An Giang Province. Scientific Journal of Can Tho University. 2018; 54(3B):125-131.

[25] Giao N.T. Surface water quality assessment using phytoplankton and zoobenthos: a case study at Bung Binh Thien, An Giang Province, Viet Nam. Journal of Viet Nam Environment. 2020; 12(1):7-16. 